\title{
The influence of landscape change on multiple dimensions of human-nature connectedness
}

\author{
Maraja Riechers $^{1}$, Ágnes Balázsi ${ }^{2}$, David J. Abson ${ }^{1}$ and Joern Fischer ${ }^{1}$
}

\begin{abstract}
Human-nature connectedness is hailed as a potential remedy for the current sustainability crisis, yet it is also deeply affected by it. Here, we perform a comprehensive assessment of human-nature connectedness that includes material, experiential, cognitive, emotional, and philosophical dimensions. We show that these dimensions of human-nature connectedness are strongly interlinked, especially via emotional and experiential connectedness. Our findings showcase a cross-country comparison of four focal landscapes in Transylvania, Romania and Lower Saxony, Germany, which represent gradients from minor and gradual to relatively major and rapid landscape change. Based on content analysis of 73 in-depth interviews, we show that landscape change was seen by the interviewees to have a strong, and often negative, influence on multiple dimensions of human-nature connectedness. Focusing only on isolated dimensions of human-nature connectedness could inadvertently exacerbate the sustainability crisis because unawareness about relationships between dimensions of connectedness may lead to false predictions regarding policy implications.
\end{abstract}

Key Words: agricultural intensification; landscape sustainability science; smallholder farming; social-ecological systems

\section{INTRODUCTION}

Humanity has already passed planetary boundaries (Rockström et al. 2009), and status quo trajectories of human behavior continue to exacerbate the threats to our planet (Steffen et al. 2015, IPCC 2018). For terrestrial systems, unsustainable trajectories can be readily observed by studying landscape change expressed through the sociocultural consequences of land-use and land-cover changes (Bürgi et al. 2004). The structural simplification of landscapes through abandonment or intensification has long been recognized as a key threat to terrestrial ecosystems, negatively influencing wild and farmland biodiversity (Green et al. 2005, Tscharntke et al. 2005), the stability of farm incomes (Di Falco and Perrings 2003, Abson et al. 2013), and the diversity of crop varieties (FAO 2011). Moreover, recent studies highlight negative effects of landscape simplification on rural communities (Riechers et al. 2020). Landscape change, in turn, is closely interlinked with other unsustainable social-ecological trends such as anthropogenic climate change (IPCC 2014) and rising demand for energy-rich foods (Khoury et al. 2014).

Although the ecological consequences caused by landscape change are well documented (e.g., Foley et al. 2011), landscape change can also have detrimental effects on human-nature connectedness (Chan et al. 2016). These effects could lead to a downward spiral of ever increasing disconnection of people and societies from nature, which may further exacerbate the global environmental crisis by enhancing unsustainable behavior patterns (Pyle 2003, Nisbet et al. 2009, Kahn et al. 2010). In contrast, the beneficial effects of connections between humans and nature include positive outcomes for health (Maller et al. 2006, Shanahan et al. 2016), the cognitive development of children (Taniguchi et al. 2005), and overall happiness and wellbeing (Capaldi et al. 2014). Based on these outcomes, scholars state a need for strengthening human connections with nature (Folke et al. 2011, Zylstra et al. 2014). However, many calls for such "reconnection" lack concrete insights about what humannature connection means and how it might be fostered.

Literature on this topic is fragmented among disciplines and encompasses a wide range of concepts and means to operationalize notions of human-nature interactions (Ives et al. 2017). Within this field, prominent literature includes notions of a "connectedness to nature scale" (Mayer and Frantz 2004), "nature relatedness" (Nisbet et al. 2009), and "connectivity with nature" (Dutcher et al. 2007, Restall and Conrad 2015; for a more comprehensive overview, see Ives et al. 2017). What is missing to date is work that recognizes multiple dimensions of human-nature connectedness and systematically links these dimensions to important features of social-ecological change such as landscape change.

To address this gap, we use a multidimensional conceptualization of human-nature connectedness and apply it to four contrasting landscapes undergoing change. Drawing on Ives et al. (2017, 2018), we recognize five dimensions. (1) The material dimension includes food, fuel, or other goods; research on this dimension has focused largely on biophysical flows (Wackernagel et al. 1999, Haberl et al. 2004, Dorninger et al. 2017), including teleconnections (Yu et al. 2013). (2) The experiential dimension relates to activities in nature and is based on decades of work, e.g., works by Miller (2005), Soga and Gaston (2016), and Keniger et al. (2013). (3) The emotional dimension spans aspects such as spirituality, aesthetics, and place attachment (Kals et al. 1999, Stedman 2003, Brown and Raymond 2007). (4) The cognitive dimension captures awareness and knowledge about natural systems (e.g., Bradley et al. 1999, Schultz 2001, 2002). (5) The philosophical dimension relates to conceptions of humanity's place in nature (e.g., van den Born 2008, Raymond et al. 2013). These five dimensions cover a multitude of disciplines and conceptual framings that together span decades of research in their respective fields. Here, we do not aim to provide a literature review or an in-depth analysis of these categories (for

${ }^{1}$ Faculty of Sustainability, Leuphana University Lueneburg, ${ }^{2}$ Ecosystem Services Laboratory, Environmental Sciences, Sapientia Hungarian University of Transylvania 
that, refer to Ives et al. 2017, 2018); rather, we aim to give a balanced and, therefore, simplified overarching empirical assessment of these dimensions. To reach this aim, we studied each of these five dimensions in four contrasting cultural landscapes in two countries (Romania and Germany), which represent a gradient from minor and gradual to relatively major and rapid landscape change. Drawing on data from all four landscapes, we sought to identify local perceptions of humannature connectedness, to characterize relationships among different dimensions of human-nature connectedness, and to elicit the interplay between landscape change and human-nature connectedness.

\section{METHODS}

\section{Focal landscapes}

We focused on four landscapes: two in Transylvania, Romania, namely Erdővidék (Covasna county) and Aranyosszék (Cluj and Alba counties; Fig. 1); and two in Lower Saxony, Germany, namely Bispingen (district Heidekreis) and Dötlingen (district Oldenburg). The focal areas capture a gradient of minor and gradual (Erdővidék, Romania and Bispingen, Germany) and more rapid and major (Aranyosszék, Romania and Dötlingen, Germany) landscape change in their respective countries. Further, in all four focal areas, prior research was undertaken that facilitated the contextualization of our empirical study and the data collection process. Although both countries, and all four focal landscapes, have differing political, economic, and social place-specific differences, we compiled results from the four focal areas to show overall trends and differences in human-nature connectedness between the countries (for details, see Balázsi et al. 2019, Riechers et al. 2019). Our qualitative empirical work with large sample sizes allowed us to combine detailed place-based knowledge with a cross-country comparison.

Fig. 1. Example landscape photographs and descriptions of the four focal landscapes.

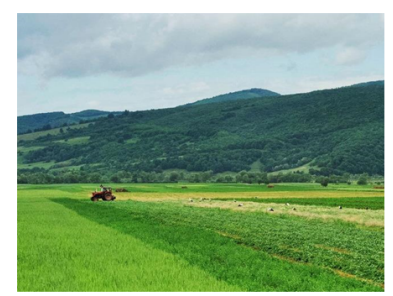

(a) Erdővidék, Covasna County

Smallholder dominated cultural landscape; minor and gradual landscape change

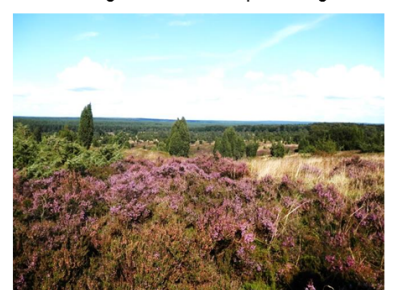

(c) Bispingen, district Heidekreis Agriculture and infrastructure development limited; moderate rate of landscape change

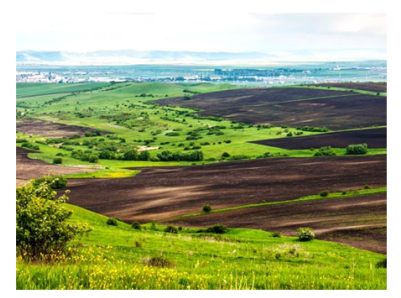

(b) Aranyosszék, Cluj County Adjacent to urban \& industrial areas moderate rate of landscape change

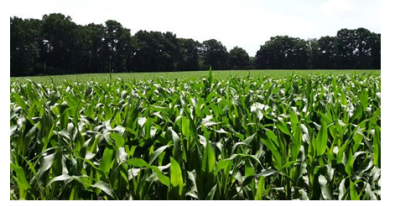

(d) Dötlingen, district Oldenburg Intensive agriculture; rapid \& major landscape change
Erdővidék is a smallholder-dominated cultural landscape, with large patches of forest and grassland and abundant wildlife. The landscape has changed only very slowly over the centuries, including during Romania's transition periods from a presocialist to socialist and now democratic society. Driven by socioeconomic and institutional change, increases in both land abandonment and intensification are considered possible in the foreseeable future (Hartel et al. 2016). Although changes have been slow in Erdővidék to date, ongoing governance challenges and socioeconomic changes could pose a risk to the landscape and its social structures in the long run (e.g., Horcea-Milcu et al. 2018). Local industry declined in the period of socialism, and Erdővidék struggles with poor socioeconomic viability and emigration of its youth. However, infrastructure development has increased in the last decade because of access to European Union (EU) funds.

The landscape in Aranyosszék is flat, crop-dominated, and subject to strong urban influences because of its proximity to the cities of Cluj-Napoca and Turda. Following Romania's accession to the EU in 2007, land-use intensity has increased, and smallholder vegetable cultivation has been increasingly replaced by industrial croplands. Family farming is declining because of an ageing population and strong competition with supermarkets. However, industrial development and small businesses have increased due to improvements in infrastructure.

The landscape in Bispingen (district Heidekreis) lies in eastern Lower Saxony and partly inside the Lueneburger heath nature park (protected under Germany's federal nature conservation act), which was established in 1907. Environmental protection laws have slowed landscape change because of restrictions to agricultural intensification and large-scale infrastructure projects. Especially for the agricultural sector, these limitations have posed economic challenges, making small-scale farming increasingly unviable and causing conflicts between farmers and nature park authorities. Tourism is an important income source for people within the landscape.

The landscape in Dötlingen (district Oldenburg), located in midwest Lower Saxony, has changed substantially over the last 20 years because of agricultural intensification, including the expansion of maize cultivation, mass animal husbandry, and biogas production. Associated drivers have included EU agricultural subsidies, as well as national subsidies for renewable energy production. In the district of Oldenburg, the proportion of agricultural land under maize production increased from $18 \%$ in 1995 to $33 \%$ in 2016 (Landesamt für Statistik Niedersachsen $2018 a, b)$ while decreases have been observed in water and air quality (Velthof et al. 2014).

\section{Data collection}

To understand different dimensions of human-nature connectedness, the relation between these dimensions, and how they are influenced by landscape change, we used problem-centred interviews (Flick 2006). Interviews were held in Romanian, Hungarian, and German using a semistructured interview guideline, which was partly adjusted to the interviewees' profession (Atteslander 2006; see Appendix 1 for full interview guidelines). The guideline included sections on interviewees' material, experiential, cognitive, emotional, and philosophical connectedness, which were assessed through questions on the use of local natural products, habits and frequency of nature visits, 
knowledge of nature and the landscape, perception of beauty, favorite places, and the feeling of and attachment to their homes. Regarding landscape change, we asked specifically for perceived changes in the recent decades, how these changes influenced interviewees' lives, and how interviewees perceived the trajectory of changes for the decades to come. The interview guidelines were adjusted to fit the local context in the respective countries (Appendix 1). Because of different historical events in Romania and Germany, the discussion around landscape change and its drivers led to the capture of different time spans. Whereas most interviewees in Romania felt a need to explain the drastic political, social, and economic changes in the country starting in the socialist area from 1947 onward, German interviewees typically focused on changes in the last 20 to 40 years.

For the interviews, we addressed informed laypersons and experts who we expected to be connected to a given landscape based on prior information about actors and actor groups or organizations in the focal areas. Those areas were mainly related to agriculture, forestry, policy-making regarding environmental issues, priests, and long-term inhabitants, usually with a high level of civil engagement. Based on these initial interviews, we used snowball sampling to reach other potential interviewees (Flick 2006). The interviewee age ranged from participants in their 30s to $90 \mathrm{~s}$. Although we aimed for gender balance, more men than women were interviewed because of the social structure in agriculture and politics. This sampling approach resulted in a total of 73 interviews with an average length of 71 min (Erdővidék: $N=20$, Aranyosszék: $N=19$, Bispingen: $N=17$, Dötlingen: $N=17$ ).

\section{Data analysis}

Interviews were transcribed verbatim and analyzed using MaxQDR Plus 12 (VERBI Software, Berlin, Germany) and NVivo 10 (QSR International, Doncaster, Australia). Data were analyzed using summarizing qualitative content analysis (Mayring 2008). Based on the five dimensions of human-nature connectedness as described by Ives et al. (2017, 2018), we created a deductive coding tree that was iteratively adjusted inductively, driven by the narratives and topics raised by the interviewees. The deductive approach helped to focus existing theories and allowed comparability between the focal areas; it focused primarily on the five predefined categories of human-nature connectedness and known aspects of landscape change. The inductive approach ensured that all relevant specificities and topics not covered in the coding tree were able to be captured and unexpected statements made by interviewees were sufficiently incorporated. Codes were successively grouped together to form categories of an increasing level of abstraction (Mayring 2008). Table 1 shows the resulting final categories and their subdivision (subcategories) within the five dimensions of human-nature connectedness. For example, one type of emotional connection is captured by the category "spiritual and religious feelings". This category, in turn, is divided into two subcategories: "Christian-based" and "mystical" connections.

To assess relationships between different dimensions of humannature connectedness, we extracted stated relationships. For example, we may have coded an interviewee's statement into the category of emotional connectedness such as sense of place, which was related by the interviewee to experiential connectedness such as social activities in nature (e.g., "I feel like home here so I spend a lot of time outside"). Another interviewee might have spoken of material connections such as provision of food, and linked this connection to experiential activities such as a high frequency of nature visits (e.g., "I collect mushrooms in the forest every week"). Such relations were captured and used to illustrate relations between the different dimensions of human-nature connectedness. The direction of the relationships and their strength were not coded because they typically could not be identified clearly from the qualitative statements made by the interviewees. The same procedure was used to combine information on landscape change and categories of human-nature connectedness. To guarantee anonymity, we do not give the age, gender, or profession of the interviewees here.

\section{RESULTS}

We first identify perceptions of human-nature connectedness (Table 1) and highlight their interrelations (Fig. 2). We then illustrate the interplay between landscape change and humannature connections.

\section{Dimensions of human-nature connectedness and their relationships}

Interviewees stated that their material connections to nature stemmed from the use of fuel (biogas, wood), food (collected, selfgrown), building material, collection of artisan goods, owning land, agriculture and forestry, and the use of regional products. In Transylvania, strong material connections stemmed from traditional smallholder farms because using materials from nature for subsistence (firewood, food, etc.) was very common Interviewees related material connectedness to experiential and emotional connectedness (Fig. 2): experiential connectedness through extraction of goods and time spent on working the land; emotional connectedness through a sense of responsibility and sense of belonging to particular places (e.g., where inhabitants produced food, hay, or collected water).

Experiential connections were identified as frequent nature visits, especially close to home. They included recreation and social activities in nature. The stimulation of the senses and motoric development, and especially interviewees' own childhood experiences, were seen as constituents of experiential nature connectedness. Experiential connectedness, in addition to its aforementioned relation to material connectedness, was linked by the interviewees to emotional connectedness (Fig. 2). In particular, social activities in natural settings (experiential) were related to inhabitants perceiving a sense of place (emotional). When discussing their love for nature (emotional), interviewees often referred back to childhood experiences in nature (experiential).

Cognitive connections were defined as learning by doing and observing in nature, especially through an active awareness of daily encounters with nature. Self-identification with the landscape, knowledge about the environment and farming practices, and especially the knowledge and visibility of specific historical events and cultural sites were perceived as key components of cognitive connectedness to nature. In addition, raising awareness for nature through education (formal and informal), active communication about environmental topics in peer-groups, and general environmental education were deemed as another pillar for cognitive connectedness. Cognitive 
Table 1. Results of the cross-country, summarizing content analysis, grouped into five dimensions of human-nature connectedness. Categories and subcategories are themes that emerged from the interview data.



connectedness was related to philosophical, experiential, and emotional connectedness (Fig. 2). For example, through the discussion of sustainability (philosophical), interviewees linked their knowledge (cognitive) with a normative perspective of human-nature relationships, and in that context, they often expressed sadness regarding the current landscape change (emotional). Cognitive connectedness was further related to emotional connectedness because the knowledge and awareness of a given landscape's specific history and culture fed into a strong sense of place.

Emotional connections were partly positive, stemming from love for nature, spiritual and religious connections to it, aesthetics, and, moreover, feeling inspired and creative by being in nature. Feelings that fostered emotional connectedness were further related to agency, responsibility and ownership, a strong sense of place, and curiosity to look for new and special encounters or experiences in nature. Emotional connections also came from negative emotions such as fear and sadness regarding the state of the landscape and a dislike of industrialized livestock production. Emotional connectedness, in addition to the aforementioned relations, was linked by the interviewees with philosophical connectedness (Fig. 2). As an example, the normative notion of the need to preserve the landscape (philosophical) and the discussion of what nature is and who owns it (philosophical) was related to a fear regarding current landscape changes (emotional).

Philosophical connections were identified from discussions around differing notions of sustainability or the need to be fit for the future (from the German: zukunftsfähig). A critical view of consumerism and the constant need for growth (e.g., more products or more farmland) increased philosophical nature connectedness. Moreover, the perceived importance of environmental protection, preservation of traditions, the highlighted responsibilities of agriculture and forestry, and the discussion of the definition of nature (and for whom it exists) were pillars for philosophical connections. For philosophical connectedness, in addition to its aforementioned relations, interviewees also saw a link with material connectedness (Fig. 2). The discussion of the use of regionally produced goods (material) was linked to negative opinions of consumerism in general (philosophical). For example, some interviewees stated a lack of trust in commercialized production and critically questioned 
Fig. 2. Graphical representation of relationships among the five dimension of human-nature connectedness (material, experiential, cognitive, emotional, and philosophical; from Ives et al. 2018) based on the content analysis of four focal areas (see details in Table 1). Lines indicate relationships between the categories of human-nature connectedness as highlighted by the interviewees. For ease of interpretation, lines from experiential and emotional connections are shown in blue and red, respectively.

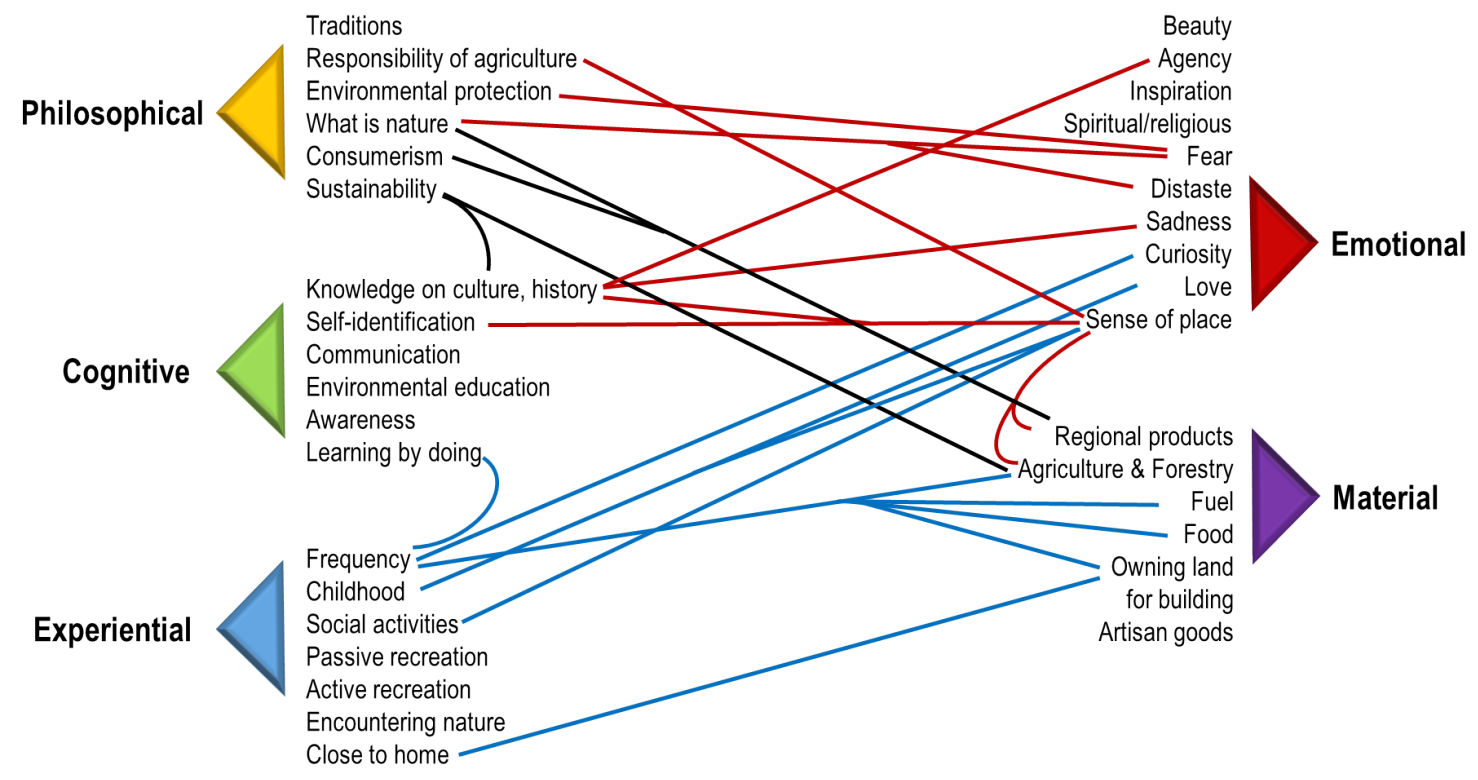

modern consumption patterns such as high rates of processed meat consumption.

\section{Interplay between landscape change and human-nature connectedness}

In all four landscapes, material connectedness was perceived to be declining due to the decoupling of consumers from local production processes and the increased consumption of nonlocal goods. In both landscapes in Transylvania, landscape change was related to changes in state governance, which resulted in shifts in land ownership. Nationalization and collectivization of private property by the state during communism led to a loss of material connectedness because the goods produced were often allocated to other localities. However, when connections to inhabitants' own land were reestablished following the collapse of communism, socioeconomic conditions changed as well, preventing a durable reconnection of material connectedness:

\section{[...] the land was given back after the 90s. Everyone turned back to the practices used before the collectives [were established]. Everyone did their share, as they could, with horses, oxen, and cows. They were struggling with it for about 10 years. [...] now they want to get rid of it. Now we don't know how to convince farmers to rent our land. (Aranyosszék, teacher).}

In Lower Saxony, smaller agricultural farms and local products declined because of global and national political and economic drivers. Many goods that still provide a material connection to nature have changed from being livelihood necessities to becoming symbols of regional identity (e.g., specific regional varieties of potatoes or honey). Because of the increase in biogas plants and wind parks, some villages, especially in Dötlingen, have become energy self-sufficient. Although this self-sufficiency provides a new type of material connection to nature, it has come at the cost of a large proportion of land being used for maize production, which is viable largely in combination with mass animal husbandry.

Whereas experiential connectedness in Lower Saxony was perceived as stable, in Transylvania, it transformed with a change in rural lifestyles. Recreation and leisure increased while farming experiences decreased. Moreover, high rates of emigration weakened the experiential connections with "home":

\section{In Erdövidék, more than $60 \%$ of young people leave their home landscape because of a lack of jobs. Some turn back after making some money, some commute between home and abroad, [some] never look back. The last two are the worst because the majority remains [abroad]. Those who come back build their homeland at the beginning, but then are trapped again when their finances run out. (Erdővidék, teacher).}

Further, in Transylvania, cognitive connectedness to nature was shaped by shifts in knowledge systems and political ideologies (presocialist, socialist, democratic). The shifts affected individuals and the community's collective cognition regarding the management of the landscape and its resources. Most notably, inherited and experience-based knowledge became increasingly supplanted by formal and disciplinary knowledge. Shifts in political ideologies (e.g., socialism, communism, capitalism, environmentalism) appear to influence cognitive connectedness. Interviewees stated that the traditional knowledge of the 
community might get lost because of a lack of interest in it by the younger generation.

\section{The knowledge about nature, of what nature is, I think, they don't get that now, [...] the relation [to nature] which is inherited. Obviously, inherited knowledge includes the names of trees and things. [...] In other words, there is an emotional bond, whereas in learned knowledge, we just know a lot of things. (Aranyosszék, priest).}

Cognitive connections in the two Lower Saxony focal areas were often generated through stimulating and exciting experiences such as visiting new places, rare sightings of particular plants or animals, or special atmospheres (Table 1):

\section{[The view] has something mystical. The wide plains and the juniper [Juniperus communis], and, when the fog lies upon it and the sun comes through. That... that is wonderful. (Bispingen, Tourism).}

Such cognitive stimulating experiences were often connected to a structurally diverse landscape, which, in turn, was connected to emotional connectedness.

In fact, in all four landscapes, emotional connectedness was linked by the interviewees to a structurally diverse landscape. The most highlighted themes related to emotional connectedness were special landscape features, seasons, animals, and a wide view of the landscape (Table 1). In Transylvania, emotional connections came from stories about social relationships that existed in the past, for example, working the land gathered the community in nature. Interviewees talked nostalgically about lost traditions (e.g., cleaning pastures in spring, community work for hay making) and social relationships that had become weakened because of changing lifestyles. In Lower Saxony, and Dötlingen specifically, interviewees expressed sadness, especially with regard to the topic of environmental protection and the current landscape trajectory. This sadness was linked to a feeling of loss of agency and ownership of nature, while still feeling a sense of responsibility for it, as exemplified by a story in which a tree was cut illegally due to agricultural expansion:

\section{My favourite tree has been cut down. I thought: This cannot be true. [... and even though I tried to find the responsible persons] the big beautiful tree, which I loved, was of course gone. (Dötlingen, employee in an environmental protection authority).}

Most interviewees showed negative feelings regarding landscape changes. In Dötlingen, where landscape change had been most rapid, anger and sadness for the perceived destruction of the landscape, as well as for the resulting conflicts affecting the communities' social relationships, were particularly pronounced. However, in all focal areas, sense of place, love for nature, and spiritual expressions remain important.

Themes related to philosophical connectedness in Transylvania included meanings of nature, heritage values, and the role and place of human beings in the natural world, revealing sustainability issues (although this term was rarely used). The most common associations with sustainability were respect for nature and family heritage. The family's land and traditions regarding its management occupied a central role, especially in Erdővidék. Philosophical connectedness in the Lower Saxony focal areas was defined by the influence of landscape change. Differing understandings of who owns land and the landscape, as well as contrasting definitions of what constitutes nature, showed differing paradigms among the local people. The current trajectory of agriculture, perceived to be driven by a paradigm of growth, was often seen to be contradictory to environmental protection:
They always say - you have to do more, you have to get bigger [agriculture but also in general...] or is this just a dream of some (economic) growth? I don't know. Is there an end somewhere? (Dötlingen, young farmer).

\section{DISCUSSION}

Drawing on four different landscapes in two countries, we elicited the following four ideas. First, the experiential and emotional dimensions of human-nature connectedness seemed to play a key role for our interviewees and had links to many other dimensions. This interpretation might show that those two dimensions could foster, through ripple effects, a multitude of connections when strengthened. Second, in general, many human-nature connections were linked to each other, and reinforcing and balancing relationships seem likely to influence ambitions to strengthen overall human-nature connectedness. Third, landscape change was stated to be eroding and changing humannature connectedness in the focal areas. Lastly, there are a multitude of human-nature connections, and hence, research should not be solely compartmentalized into disciplines. Although in-depth specific studies are of utmost importance, overarching synthesizing studies should not be left aside. Knowledge about the heterogeneous and context-specific character of human-nature connectedness is therefore crucial.

Emotional and experiential connectedness had the most connections to the other dimensions and seem to act as key connectors (Fig. 2). In particular, emotional connections such as love (Wilson 1984, Schultz 2001) and place attachment (Stedman et al. 2004) had multiple connections to other dimensions. Likewise, the experiential connection of frequent visits to nature (Soga and Gaston 2016) was linked to other dimensions of connectedness (Fig. 2). Because disconnection from nature is likely to exacerbate the global sustainability crisis, it is important to find concrete ways to foster and strengthen human-nature connectedness. However, most calls for reconnection have remained vague and abstract and lack concrete insights about a comprehensive notion of what this connection means and how to foster it. Our findings point to a multidimensional notion of human-nature connectedness with many interlinkages among those dimensions. Our results showed that the experiential and emotional dimensions of human-nature connectedness could be particularly important entry points when trying to enhance and strengthen human-nature connectedness because these two dimensions were linked to many other connections. A possible focus on emotional connections could be done via art (Riechers et al. 2019) or through a focus on personal sustainability (Ives et al. 2020).

Apart from the key role of experiential and emotional connectedness (Fig. 3), we found a high degree of interconnectedness among these dimensions. As an example, in our results, a strong sense of place (an emotional connection) was related to philosophical (e.g., preservation of traditions), material 
(e.g., regional products), cognitive (e.g., knowledge of regional history and culture), and experiential (e.g., social activities) dimensions of connectedness to nature. Although we do not know the causal relationships among these links, these findings suggest that there will likely be ripple effects when there is a change in any dimension of human-nature connectedness, positive or otherwise. Our findings thus emphasize the heterogeneous character of human-nature connectedness and the attention to dynamic interlinkages needed to study this phenomenon comprehensively. Reinforcing the relationships between different types of connections, for example, could foster useful ripple effects (or even reinforcing feedbacks) across multiple dimensions of connectedness.

Fig. 3. Schematic depiction of the current strength of material, experiential, cognitive, emotional, and philosophical connectedness in the four focal areas of Erdővidék, Aranyosszék, Dötlingen, and Bispingen. Bars are a subjective interpretation based on the collective interview statements from each focal area and depicted here schematically to allow comparison among the focal areas.



Erdővidék, Romania



Dötlingen, Germany

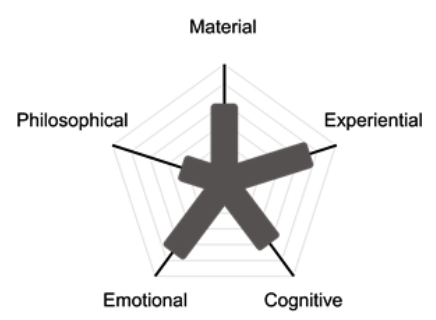

Aranyosszék, Romania

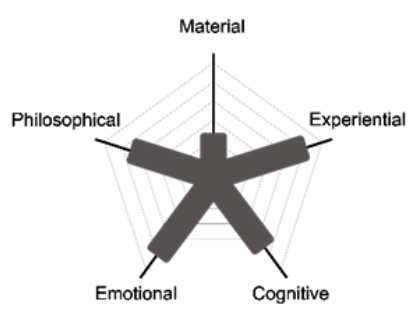

Bispingen, Germany
Across the four focal areas, we found the trend that rapid landscape change appeared to decrease the overall levels of connectedness. This trend could continue due to continued simplification of landscapes, and also as values might change slower than the landscapes, creating a situation in which values are linked more to memories of landscapes than to the currently existing ones (Horcea-Milcu et al. 2018). Even though we found vastly differing political contexts in which the landscapes changed over the last 20 years (Balázsi et al. 2019, Riechers et al. 2019), the trajectory of changing human-nature connectedness was similar. The five dimensions of human-nature connectedness appeared to be relevant for all four focal areas, and discussions around landscape change touched upon comparable issues in both Romania and Germany. We thus consider it plausible that similarities can also be observed in other rural landscapes elsewhere in the world. Indeed, a recent comparison considering additional study systems suggests there were generalizable links between landscape change and the erosion of cultural and individual identity, human-nature connectedness, and sense of agency (Riechers et al. 2020). However, despite the potential value for human-nature connectedness, structural landscape diversity is deteriorating in many parts of the world (Foley et al. 2005), as is small scale agriculture (e.g., Mikulcak et al. 2013). In areas of rapid landscape change, sense of place and biocultural values are at risk (Hartel et al. 2018). Finally, trajectories favoring economic growth over social equity not only lead to landscape simplification but can also lead to an increase in conflicts (Scoones et al. 2019). Quantitative analyses of such interlinkages could show insights into complex patterns between landscape change and humannature connections in their various forms (Jansson and Polasky 2010, Dobbs et al. 2014) and could potentially help to inform decision makers about large-scale management processes.

Our empirical study is the first to apply the interdisciplinary framework proposing five dimensions of human-nature connectedness by Ives et al. $(2017,2018)$. The conceptual framework was broad enough to cover all important aspects of human-nature connectedness that we identified through the deductive and inductive coding process. It allowed us to capture a wide variety of relationships between different types of connections and to include a focus on how these relationships were perceived to alter through landscape change. Assessing material, experiential, cognitive, emotional, and philosophical perceptions of connectedness seemed to capture heterogeneity successfully, both in concepts and people's experienced realities, and opens the possibility for integrating different disciplinary perspectives on human-nature connectedness, including biophysical flows between societies and nature (Wackernagel et al. 1999, Haberl et al. 2007, Dorninger et al. 2017), behavioural approaches (Capaldi et al. 2014, Soga and Gaston 2016), and approaches that focus more strongly on philosophical aspects (Dutcher et al. 2007, Nisbet et al. 2009).

\section{CONCLUSION}

The empirical work from four different landscapes in Romania and Germany highlight four major results. We found multiple links among material, experiential, cognitive, emotional, and philosophical dimensions of human-nature connectedness in the lived experiences of our interviewees. Landscape change, in all four landscapes, showed a change and a decrease in humannature connectedness, and hence, we hypothesize that a similar trend might be observable in other landscapes. Improved humannature connectedness has been hailed as a possible remedy to the global sustainability crisis. However, the relationship between human-nature connectedness appears to be mutually reinforcing such that there is a two-way link; that is, human-nature connectedness can also be eroded quickly through unsustainable landscape trajectories. To combat a spiral of disconnectedness and landscape change, we suggest focusing on the importance of strong emotional and experiential connectedness as pivotal points in overarching human-nature connectedness and reinforcing and balancing relationships among the dimensions. We acknowledge that societal changes (economic, cultural, etc.) are likely to influence human-nature connectedness. However, such societal changes drive landscape change; therefore, we believe that landscape change acts as a useful phenomenon though which such complex societal changes are played out and can be explored. 
Whether landscape change is a proximate or ultimate driver of changing human-nature connectedness is a question deserving further research.

We also suggest that more firmly establishing the causal links between human-nature connectedness and sustainability could be an important research focus. Human-nature connectedness is not something that can be readily manipulated across entire social-ecological systems or landscapes, and sustainability is also a highly complex and multidimensional concept. These factors pose challenges for disentangling the relationship between changes in human-nature connectedness and sustainability outcomes. Finally, applying the conceptual framework used here to other contrasting landscapes would be useful to assess whether there are indeed broadly applicable interventions that could foster human-nature connectedness and thereby benefit sustainability.

Responses to this article can be read online at: http://www.ecologyandsociety.org/issues/responses. $\mathrm{php} / 11651$

\begin{abstract}
Acknowledgments:
We thank the interviewees for their collaboration. This research is supported by the Volkswagenstiftung and the Niedersächsisches Ministerium für Wissenschaft und Kultur (grant A112269). This research draws on work undertaken in a large transdisciplinary research project (Leverage Points for Sustainability Transformation). The authors acknowledge and thank all project members for their ideas and input in the early stages of this work, even where they are not listed as authors. Full details of project members and their research are available at https:/lleveragepoints.org. Author A. B. has also contributed to a project supported by the Romanian National Authority for Scientific Research and Innovation (CCCDI-UEFISCDI): ERA-FACCE-STACCATO-3 (BiodivERSAFACCE2014-47).
\end{abstract}

\section{Data Availability Statement:}

The data are not publicly available due to restrictions; they contain information that could compromise the privacy of our interviewees. For questions please contact M. R.

\section{LITERATURE CITED}

Abson, D. J., E. D. G. Fraser, and T. G. Benton. 2013. Landscape diversity and the resilience of agricultural returns: a portfolio analysis of land-use patterns and economic returns from lowland agriculture. Agriculture and Food Security 2(1):2. https://doi. org/10.1186/2048-7010-2-2

Atteslander, P. 2006. Methoden der empirischen Sozialforschung. 11th edition. Erich Schmidt Verlag, Berlin, Germany.

Balázsi, Á., M. Riechers, T. Hartel, J. Leventon, and J. Fischer. 2019. The impacts of social-ecological system change on humannature connectedness: a case study from Transylvania, Romania. Land Use Policy 89:104232. https://doi.org/10.1016/j.

landusepol.2019.104232
Bradley, J. C., T. M. Waliczek, and J. M. Zajicek. 1999. Relationship between environmental knowledge and environmental attitude of high school students. Journal of Environmental Education 30(3):17-21. https://doi.org/10.1080/00958969909601873

Brown, G., and C. Raymond. 2007. The relationship between place attachment and landscape values: toward mapping place attachment. Applied Geography 27(2):89-111. https://doi. org/10.1016/j.apgeog.2006.11.002

Bürgi, M., A. M. Hersperger, and N. Schneeberger. 2004. Driving forces of landscape change — current and new directions. Landscape Ecology 19(8):857-868. https://doi.org/10.1007/ s10980-004-0245-8

Capaldi, C. A., R. L. Dopko, and J. M. Zelenski. 2014. The relationship between nature connectedness and happiness: a meta-analysis. Frontiers in Psychology 5:976. https://doi. org/10.3389/fpsyg. 2014.00976

Chan, K. M. A., P. Balvanera, K. Benessaiah, M. Chapman, S. Díaz, E. Gómez-Baggethun, R. Gould, N. Hannahs, K. Jax, S. Klain, G. W. Luck, B. Martín-López, B. Muraca, B. Norton, K. Ott, U. Pascual, T. Satterfield, M. Tadaki, J. Taggart, and N. Turner. 2016. Opinion: Why protect nature? Rethinking values and the environment. Proceedings of the National Academy of Sciences 113(6):1462-1465. https://doi.org/10.1073/pnas.1525002113

Di Falco, S., and C. Perrings. 2003. Crop genetic diversity, productivity and stability of agroecosystems. A theoretical and empirical investigation. Scottish Journal of Political Economy 50 (2):207-216. https://doi.org/10.1111/1467-9485.5002006

Dobbs, C., D. Kendal, and C. R. Nitschke. 2014. Multiple ecosystem services and disservices of the urban forest establishing their connections with landscape structure and sociodemographics. Ecological Indicators 43:44-55. https://doi.org/10.1016/j. ecolind.2014.02.007

Dorninger, C., D. J. Abson, J. Fischer, and H. von Wehrden. 2017. Assessing sustainable biophysical human-nature connectedness at regional scales. Environmental Research Letters 12(5):055001. https://doi.org/10.1088/1748-9326/aa68a5

Dutcher, D. D., J. C. Finley, A. E. Luloff, and J. B. Johnson. 2007. Connectivity with nature as a measure of environmental values. Environment and Behavior 39(4):474-493. https://doi. org/10.1177/0013916506298794

Flick, U. 2006. Qualitative Sozialforschung: eine einführung. Fourth edition. Rowohlt Taschenbuch, Hamburg, Germany.

Foley, J. A., R. Defries, G. P. Asner, C. Barford, G. Bonan, S. R. Carpenter, F. S. Chapin, M. T. Coe, G. C. Daily, H. K. Gibbs, J. H. Helkowski, T. Holloway, E. A. Howard, C. J. Kucharik, C. Monfreda, J. A. Patz, I. C. Prentice, N. Ramankutty, and P. K. Snyder. 2005. Global consequences of land use. Science 309 (5734):570-574. https://doi.org/10.1126/science.1111772

Foley, J. A., N. Ramankutty, K. A. Brauman, E. S. Cassidy, J. S. Gerber, M. Johnston, N. D. Mueller, C. O'Connell, D. K. Ray, P. C. West, C. Balzer, E. M. Bennett, S. R. Carpenter, J. Hill, C. Monfreda, S. Polasky, J. Rockström, J. Sheehan, S. Siebert, D. Tilman, and D. P. M. Zaks. 2011. Solutions for a cultivated planet. Nature 478(7369):337-342. https://doi.org/10.1038/nature10452 
Folke, C., Å. Jansson, J. Rockström, P. Olsson, S. R. Carpenter, F. S. Chapin III, A.-S. Crépin, G. Daily, K. Danell, J. Ebbesson, T. Elmqvist, V. Galaz, F. Moberg, M. Nilsson, H. Österblom, E. Ostrom, Å. Persson, G. Peterson, S. Polasky, W. Steffen, B. Walker, and F. Westley. 2011. Reconnecting to the biosphere. Ambio 40 (7):719. https://doi.org/10.1007/s13280-011-0184-y

Food and Agriculture Organization (FAO). 2011. Report of the Panel of Eminent Experts on ethics in food and agriculture: fourth session 26-28 November 2007. FAO, Rome, Italy. [online] URL: http://www.fao.org/3/i2043e/i2043e00.htm

Green, R. E., S. J. Cornell, J. P. W. Scharlemann, and A. Balmford. 2005. Farming and the fate of wild nature. Science 307 (5709):550-555. https://doi.org/10.1126/science.1106049

Haberl, H., K. H. Erb, F. Krausmann, V. Gaube, A. Bondeau, C. Plutzar, S. Gingrich, W. Lucht, and M. Fischer-Kowalski. 2007. Quantifying and mapping the human appropriation of net primary production in Earth's terrestrial ecosystems. Proceedings of the National Academy of Sciences 104(31):12942-12947. https:// doi.org/10.1073/pnas.0704243104

Haberl, H., M. Fischer-Kowalski, F. Krausmann, H. Weisz, and V. Winiwarter. 2004. Progress towards sustainability? What the conceptual framework of material and energy flow accounting (MEFA) can offer. Land Use Policy 21(3):199-213. https://doi. org/10.1016/j.landusepol.2003.10.013

Hartel, T., N. Fagerholm, M. Torralba, Á. Balázsi, and T. Plieninger. 2018. Forum: social-ecological system archetypes for European rangelands. Rangeland Ecology and Management 71 (5):536-544. https://doi.org/10.1016/j.rama.2018.03.006

Hartel, T., K. O. Réti, C. Craioveanu, R. Gallé, R. Popa, A. Ioniţă, L. Demeter, L. Rákosy, and B. Czúcz. 2016. Rural socialecological systems navigating institutional transitions: case study from Transylvania (Romania). Ecosystem Health and Sustainability 2(2):e01206. https://doi.org/10.1002/ehs2.1206

Horcea-Milcu, A. I., D. J. Abson, I. Dorresteijn, J. Loos, J. Hanspach, and J. Fischer. 2018. The role of co-evolutionary development and value change debt in navigating transitioning cultural landscapes: the case of Southern Transylvania. Journal of Environmental Planning and Management 61(5-6):800-817. https://doi.org/10.1080/09640568.2017.1332985

Intergovernmental Panel on Climate Change (IPCC). 2014. Climate change 2014: synthesis report. Contribution of Working Groups I, II and III to the Fifth Assessment Report of the Intergovernmental Panel on Climate Change. Core Writing Team, R. K. Pachauri, and L. A. Meyer, editors. IPCC, Geneva, Switzerland. [online] URL: https://www.ipcc.ch/site/assets/ uploads/2018/05/SYR_AR5 FINAL_full_wcover.pdf

Intergovernmental Panel on Climate Change (IPCC). 2018. Global warming of $1.5^{\circ} \mathrm{C}$. Summary for policy makers. IPCC, Geneva, Switzerland. [online] URL: https://www.ipcc.ch/sr15/ chapter/spm/

Ives, C. D., D. J. Abson, H. von Wehrden, C. Dorninger, K. Klaniecki, and J. Fischer. 2018. Reconnecting with nature for sustainability. Sustainability Science 13(5):1389-1397. https://doi. org/10.1007/s11625-018-0542-9
Ives, C. D., R. Freeth, and J. Fischer. 2020. Inside-out sustainability: the neglect of inner worlds. Ambio 49:208-217. https://doi.org/10.1007/s13280-019-01187-w

Ives, C. D., M. Giusti, J. Fischer, D. J. Abson, K. Klaniecki, C. Dorninger, J. Laudan, S. Barthel, P. Abernethy, B. Martín-López, C. M. Raymond, D. Kendal, and H. von Wehrden. 2017. Human -nature connection: a multidisciplinary review. Current Opinion in Environmental Sustainability 26-27:106-113. https://doi. org/10.1016/j.cosust.2017.05.005

Jansson, Å., and S. Polasky. 2010. Quantifying biodiversity for building resilience for food security in urban landscapes: getting down to business. Ecology and Society 15(3):20. https://doi. org/10.5751/ES-03520-150320

Kahn, P. H. Jr., J. H. Ruckert, R. L. Severson, A. L. Reichert, and E. Fowler. 2010. A nature language: an agenda to catalog, save, and recover patterns of human-nature interaction. Ecopsychology 2(2):59-66. https://doi.org/10.1089/eco.2009.0047

Kals, E., D. Schumacher, and L. Montada. 1999. Emotional affinity toward nature as a motivational basis to protect nature. Environment and Behavior 31(2):178-202. https://doi. org/10.1177/00139169921972056

Keniger, L. E., K. J. Gaston, K. N. Irvine, and R. A. Fuller. 2013. What are the benefits of interacting with nature? International Journal of Environmental Research and Public Health 10 (3):913-935. https://doi.org/10.3390/ijerph10030913

Khoury, C. K., A. D. Bjorkman, H. Dempewolf, J. RamirezVillegas, L. Guarino, A. Jarvis, L. H. Rieseberg, and P. C. Struik. 2014. Increasing homogeneity in global food supplies and the implications for food security. Proceedings of the National Academy of Sciences 111(11):4001-4006. https://doi.org/10.1073/ pnas. 1313490111

Landesamt für Statistik Niedersachsen. 2018a. Katasterfläche nach Nutzungsarten (17) der tatsächlichen Nutzung (Gemeinde; Zeitreihe). Gebietsstand: 1.1.2015. Landwirtschaftliche Fläche (ohne Moor \& Heide) von 1997, 2015. Landesamt für Statistik Niedersachsen, Hannover, Germany. [online] URL: https:// www1.nls.niedersachsen.de/statistik/default.asp

Landesamt für Statistik Niedersachsen. 2018b. Agrarstrukturerhebung (ab 1995) und Landwirtschaftszählung (für 1999). Data available via request to Landesamt für Statistik Niedersachsen, Hannover, Germany. https://www.statistik.niedersachsen.de/startseite/

Maller, C., M. Townsend, A. Pryor, P. Brown, and L. St Leger. 2006. Healthy nature healthy people: 'contact with nature' as an upstream health promotion intervention for populations. Health Promotion International 21(1):45-54. https://doi.org/10.1093/ heapro/dai032

Mayer, F. S., and C. M. Frantz. 2004. The connectedness to nature scale: a measure of individuals' feeling in community with nature. Journal of Environmental Psychology 24(4):503-515. https://doi. org/10.1016/j.jenvp.2004.10.001

Mayring, P. 2008. Qualitative Inhaltsanalyse: Grundlagen und Techniken. 10th edition. Beltz Verlag, Weinheim, Germany.

Mikulcak, F., J. Newig, A. I. Milcu, T. Hartel, and J. Fischer. 2013. Integrating rural development and biodiversity conservation in 
central Romania. Environmental Conservation 40(2):129-137. https://doi.org/10.1017/S0376892912000392

Miller, J. R. 2005. Biodiversity conservation and the extinction of experience. Trends in Ecology and Evolution 20(8):430-434. https:// doi.org/10.1016/j.tree.2005.05.013

Nisbet, E. K., J. M. Zelenski, and S. A. Murphy. 2009. The nature relatedness scale: linking individuals' connection with nature to environmental concern and behavior. Environment and Behavior 41(5):715-740. https://doi.org/10.1177/0013916508318748

Pyle, R. M. 2003. Nature matrix: reconnecting people and nature. Oryx 37(2):206-214. https://doi.org/10.1017/S0030605303000383

Raymond, C. M., G. G. Singh, K. Benessaiah, J. R. Bernhardt, J. Levine, H. Nelson, N. J. Turner, B. Norton, J. Tam, and K. M. A. Chan. 2013. Ecosystem services and beyond: using multiple metaphors to understand human-environment relationships. Bioscience 63(7):536-546. https://doi.org/10.1525/bio.2013.63.7.7

Restall, B., and E. Conrad. 2015. A literature review of connectedness to nature and its potential for environmental management. Journal of Environmental Management 159:264-278. https://doi.org/10.1016/j.jenvman.2015.05.022

Riechers, M., Á. Balázsi, L. Betz, T. S. Jiren, and J. Fischer. 2020. The erosion of relational values resulting from landscape simplification. Landscape Ecolology, in press. https://doi. org/10.1007/s10980-020-01012-W

Riechers, M., W. Henkel, M. Engbers, and J. Fischer. 2019. Stories of favourite places in public spaces: emotional responses to landscape change. Sustainability 11(14):3851. https://doi. org/10.3390/su11143851

Rockström, J., W. Steffen, K. Noone, Å. Persson, F. S. Chapin III, E. F. Lambin, T. M. Lenton, M. Scheffer, C. Folke, H. J. Schellnhuber, B. Nykvist, C. A. de Wit, T. Hughes, S. van der Leeuw, H. Rodhe, S. Sörlin, P. K. Snyder, R. Costanza, U. Svedin, M. Falkenmark, L. Karlberg, R. W. Corell, V. J. Fabry, J. Hansen, B. Walker, D. Liverman, K. Richardson, P. Crutzen, and J. A. Foley. 2009. A safe operating space for humanity. Nature 461 (7263):472-475. https://doi.org/10.1038/461472a

Schultz, P. W. 2001. The structure of environmental concern: concern for self, other people, and the biosphere. Journal of Environmental Psychology21(4):327-339. https://doi.org/10.1006/ jevp.2001.0227

Schultz, P. W. 2002. Inclusion with nature: the psychology of human-nature relations. Pages 61-78 in P. Schmuck and W. P. Schultz, editors. Psychology of sustainable development. Springer, Boston, Massachusetts, USA. https://doi.org/10.1007/978-1-4615-0995-0_4

Scoones, I., R. Smalley, R. Hall, and D. Tsikata. 2019. Narratives of scarcity: framing the global land rush. Geoforum 101:231-241. https://doi.org/10.1016/j.geoforum.2018.06.006

Shanahan, D. F., R. Bush, K. J. Gaston, B. B. Lin, J. Dean, E. Barber, and R. A. Fuller. 2016. Health benefits from nature experiences depend on dose. Scientific Reports 6:28551. https:// doi.org/10.1038/srep28551
Soga, M., and K. J. Gaston. 2016. Extinction of experience: the loss of human-nature interactions. Frontiers in Ecology and the Environment 14(2):94-101. https://doi.org/10.1002/fee.1225

Stedman, R. C. 2003. Is it really just a social construction?: The contribution of the physical environment to sense of place. Society and Natural Resources 16(8):671-685. https://doi. org/10.1080/08941920309189

Steffen, W., K. Richardson, J. Rockström, S. E. Cornell, I. Fetzer, E. M. Bennett, R. Biggs, S. R. Carpenter, W. de Vries, C. A. de Wit, C. Folke, D. Gerten, J. Heinke, G. M. Mace, L. M. Persson, V. Ramanathan, B. Reyers, and S. Sörlin. 2015. Planetary boundaries: guiding human development on a changing planet. Science 347(6223):1259855. https://doi.org/10.1126/science.1259855

Taniguchi, S. T., P. A. Freeman, and A. L. Richards. 2005. Attributes of meaningful learning experiences in an outdoor education program. Journal of Adventure Education and Outdoor Learning 5(2):131-144. https://doi.org/10.1080/14729670585200661

Tscharntke, T., A. M. Klein, A. Kruess, I. Steffan-Dewenter, and C. Thies. 2005. Landscape perspectives on agricultural intensification and biodiversity - ecosystem service management. Ecology Letters 8(8):857-874. https://doi.org/10.1111/ j.1461-0248.2005.00782.x

van den Born, R. J. G. 2008. Rethinking nature: public visions in the Netherlands. Environmental Values 17(1):83-109. https://doi. org/10.3197/096327108X271969

Velthof, G. L., J. P. Lesschen, J. Webb, S. Pietrzak, Z. Miatkowski, M. Pinto, J. Kros, and O. Oenema. 2014. The impact of the Nitrates Directive on nitrogen emissions from agriculture in the EU-27 during 2000-2008. Science of the Total Environment 468-469:1225-1233. https://doi.org/10.1016/j.scitotenv.2013.04.058

Wackernagel, M., L. Onisto, P. Bello, A. Callejas Linares, I. S. López Falfán, J. Méndez García, A. I. Suárez Guerrero, and M. G. Suárez Guerrero. 1999. National natural capital accounting with the ecological footprint concept. Ecological Economics 29 (3):375-390. https://doi.org/10.1016/S0921-8009(98)90063-5

Wilson, E. O. 1984. Biophilia. Harvard University Press, Cambridge, Massachusetts, USA. https://doi.org/10.2307/j. ctvk12s6h

Yu, Y., K. Feng, and K. Hubacek. 2013. Tele-connecting local consumption to global land use. Global Environmental Change 23 (5):1178-1186. https://doi.org/10.1016/j.gloenvcha.2013.04.006

Zylstra, M. J., A. T. Knight, K. J. Esler, and L. L. L. Le Grange. 2014. Connectedness as a core conservation concern: an interdisciplinary review of theory and a call for practice. Springer Science Reviews 2(1-2):119-143. https://doi.org/10.1007/s40362-014-0021-3 
1. Do you do trips in nature after work? Which places do you prefer to visit?

a When do you visit these places?

b How often do you visit these places?

c Why do you visit these places, what do you appreciate about them?

d What do you do there usually?

2. Considering these places we have just talked about, what is important for you when it comes to nature?

3. How important is nature for you to relax?

4. Are there any places in the area that you find particularly pleasant or beautiful?

a Where are these?

b Can you describe what it is, that makes it beautiful or pleasant?

5. Are there places that you find unpleasant?

a Where are these?

b Can you describe what it is, that makes it unpleasant?

6. What is your most memorable experience of nature?

a Can you describe it?

b What made that experience special?

7. For some, their feeling of home and landscape are connected. How is that for you?

8. Did you always live in this area?

a Could you imagine moving away from here?

b If you would move to a city, what would you miss?

c Could you find the landscape that would mean home for you again?

9. Were there any visible changes in the village/town and the surrounding landscape in recent decades (e.g. during socialism, after socialism, after EU accession)?

a What did change and when?

b How you perceived those changes?

c What did cause those changes in the landscape?

d Can you point out places on the map that changed the most?

e Can you tell me about changes in agriculture?

f Can you tell me about changes in forestry?

g How did landownership change?

h How did public administration, bureaucracy change?

i How did the social and economic conditions change?

j Show me those areas where cultural events took place. Did these areas change over the last decades?

$\mathrm{k}$ How could you describe the connection/respect of old generations toward nature (e.g. grand-grandparents, grandparents, parents, interviewee's generation, and children)?

10. What do you think, in which directions will your village and the landscape change in the coming decades?

a What kind of impact might the changes have you on? 
b What changes would you like to see? Why?

11. I have here some pictures. Could you order these pictures by what you most want to see in the future in your area?

12. In some places, solar panels, micro hydropower plants or wind energy turbines have been built to capture energy from nature. What is your opinion about those?

a Do you know such here in the area?

b Did these influence the landscape?

13. Currently, local products tend to be highly marketed in Europe, yet sometimes these are more expensive. What do you think of this in your village?

a Do you pay attention if your food comes from this region?

b Do you think the region could be a self-sustainable?

c Which kind of products could the community assure to the market?

14. What do you think about nature conservation?

a Do you know about nature conservation initiatives here in the area? Could you describe them?

b In many places there are problems with nature conservation. Do those exist here in the area? What are those problems?

c Are you aware of plants and animals that only exist here in the area? Is this of importance for you?

15. Where do you get information on subjects related to nature? (e.g. nature conservation, places to visit, guidelines and policies)?

16. In how far do you share and discuss your impressions, experiences, knowledge related to nature within your family and friends? 